\title{
東南アジアモンスーンオンセットに対する陸面の役割 \\ ROLE OF LAND SURFACE CONDITIONS ON THE MONSOON ONSET IN SOUTHEAST ASIA
}

\author{
大楽浩司 1 \\ Koji DAIRAKU \\ 1正会員 工博 防災科学技術研究所 水・土砂防災研究部（テ305-0006 茨城県つくば市天王台3-1）
}

The Asian Summer Monsoon (ASM) onset occurs between late April and early May over inland Indochina, before any transitions occur along the coast. The influence of orography and soil moisture on sub-continental-scale hydrological processes was elucidated by using a regional climate model. The model reproduced many elements of the onset of the Southeast Asia Monsoon (SEAM) associated with land surface conditions, including the early and abrupt onset observed when mountain effects and relatively dry soil conditions were included in the simulations. The nonlinear effects of mountains and ground wetness, combined with realistic increases in precipitation, can modify the hydrological cycle through changes in the surface energy budget. A positive feedback between soil moisture and precipitation increases the moisture source for further precipitation in the transition period.

Key Words: Monsoon Onset, Atmosphere-landsurface Interaction, Regional Climate Model, Southeast Asia

\section{1. はじめに}

アジアモンスーンは洪水・渇水を引き起こし，モン スーンアジア地域の経済や人々の生活に大きな影響を及 ぼす.それゆえ，モンスーンの予測可能性はこの地域に おける非常に重要な関心事である. 原則的に，平均的な 循環場や降水分布は高緯度よりも低緯度において予測可 能性が高く，その変動の多くは海面水温やアルベド，土 畩水分などの境界条件によって大きく影響を受ける1).

Fasullo and Webster ${ }^{2}$ (は6月から9月の夏季モンスーンの 積算降水量について，モンスーン入り（Onset）とモン スーン明け（Withdrawal）の両方と関係があることを示 した. 東南アジアモンスーンの始まりは農業生産活動に とって非常に重要であり，引き続く夏季インド・東アジ アモンスーン活動の前兆と成りうるため, そのより良い 理解は非常に重要である.

インドシナ半島の内陸部において，アジアモンスーン に起因する降水活動は 4 月後半から 5 月の始めに開始す る.これは他の地域よりも早く，また海岸部よりも早い. この地域では 5 月中旬頃に, 発達した夏季アジアモン スーン循環が確立し，引き続いてタイの南側とボルネオ の北側の地域の陸上に留まっていた対流活動が突然北進 し，南シ十海へ広がる3), 4), 5)。この毎年起こる季節進行は
総観規模スケールの変動の影響を強く受けているが，イ ンドシナ半島において夏季アジアモンスーン循環の確立 よりも早く活発な降水活動が見られることは，地域的な 影響の重要性を示唆していると考えられる.

土壌水分と降水間のフィードバックの重要性はこれま でにも数多く研究，議論されてきており6),7)，陸域にお ける水循環過程が夏季アジアモンスーンの強度や変動と 結びついていることが指摘されている6), 8), 9). Meehl ${ }^{10)}$,

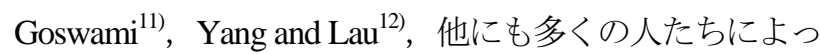
て陸面状態が海陸の熱的コントラスト形成に重要な寄与 をしていることが指摘されている。

これまで行われた研究は主に全球気候モデル （GCM）を用いて，例えば海面水温のような外部条件 (external conditions) と内部のフィードバック（internal feedbacks）について研究し，（特に土壌水分や積雪面積 を含む) 内部フィードバック過程の重要性を議論してき た。また，過去に行われたGCMによる研究では，チ ベット高原がアジアモンスーンの発達に大きな影響を及 ぼしていることが示唆されている13), 14). それに加え，タ イ北西部の山岳地域においては顕著な降水の標高依存性 が観測されており ${ }^{15)}$ ，山岳は降水の励起・強化に大きな 役割を果たしている ${ }^{16)}$.これらの研究から，土壌水分や 山岳は東南アジア地域における早く急激なモンスーンオ 
ンセットの生起に大きな役割を果たしている可能性が考 えられる.

これまでチベット高原や，海面水温，積雪や土䁃水分 がアジアモンスーンに及ぼす影響は，主にGCMを用い て研究されてきたが，東南アジアモンスーンのオンセッ トに陸面が及ぼす影響については，必ずしも明らかに なっていない, その一つの理由は, モデルの空間解像度 が粗いため, インドシナ半島における陸面過程を十分に 表現できていないことに因ると思われる。本研究は,

GAME再解析Ver.1.5を初期・境界条件とし，地域気候モデ ルを用いて乾季から雨季への移行期である1998年の4月から 5月下旬の期間，陸面の状態を変えた数值実験を行い，その 大気・陸域水循環過程の検討を行った.

\section{2. 数値モデルと数値実験}

本研究では，地域気候モデルを用いて，インドシナ半 島における夏季アジアモンスーン開始期の水循環過程に 対する陸面状態の影響の解析を行った. 数值モデルは, 3 次元非静水圧・圧縮モデル（RAMS: Regional Atmospheric Modeling System） ${ }^{17) て ゙ あ る . ~}$

雲・降水過程は，簡略化したKuo積雲パラメタリゼー ションスキーム ${ }^{18)}$ とバルク雲微物理過程，放射過程は雲 微物理過程と対応した 2 ストリーム放射過程 ${ }^{19)}$, 陸面過 程はLEAF-2 ${ }^{20)}$ ，地形データはGTOPO30，土地利用・土 地被覆情報は衛星データ（NOAA-AVHRR）に基づき USGSによって作成されたものを用いた，海面水温は OISST Ver. $2^{21}$ の週毎の観測值を時間方向に内挿して用い た.

GAME再解析データは， $0.5^{\circ} \times 0.5^{\circ}$ の水平解像度で， 6 時間毎のデータであり, Global Energy and Water Cycle Experiment (GEWEX) , Asian Monsoon Experiment Intensive Observing Period (GAME-IOP) における観測 データなどを気象庁の天気予報のための数值解析システ ムに入力したものである ${ }^{22}$. これを本数值実験の初期・ 境界条件とした. モデルは計算領域の外側 5 グリッドに おいてGAME再解析データにナッジングさせた.また, 対流圈界面より上部でも同様にナッジングした.

水平方向の空間解像度は $20 \mathrm{~km}$ で, 計算領域は経度方 向200グリッド（約4,000km），緯度方向160グリッド

(約3,200km) の領域である（図-1）。鉛直座標系は地 形に沿う $\sigma_{\mathrm{z}}$ 座標であり，鉛直方向は35層（高度約 $23.4 \mathrm{~km}$ まで），鉿直グリッドは最下層 $100 \mathrm{~m}$ から最大 $1,000 \mathrm{~m} ま$ で徐々にその格子間隔を大きくした.

本研究ではモデル内部のカオス的振る舞いによるノイ ズを低減するために，それぞれ積分開始時刻を1時間ず

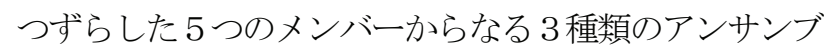
儿数值実験を行った，それぞれの実験においては，東南 アジアにおける夏季モンスーンの開始期にあたる1998年 4月1日から1998年5月25日までの約 2 ヶ月間の積分を

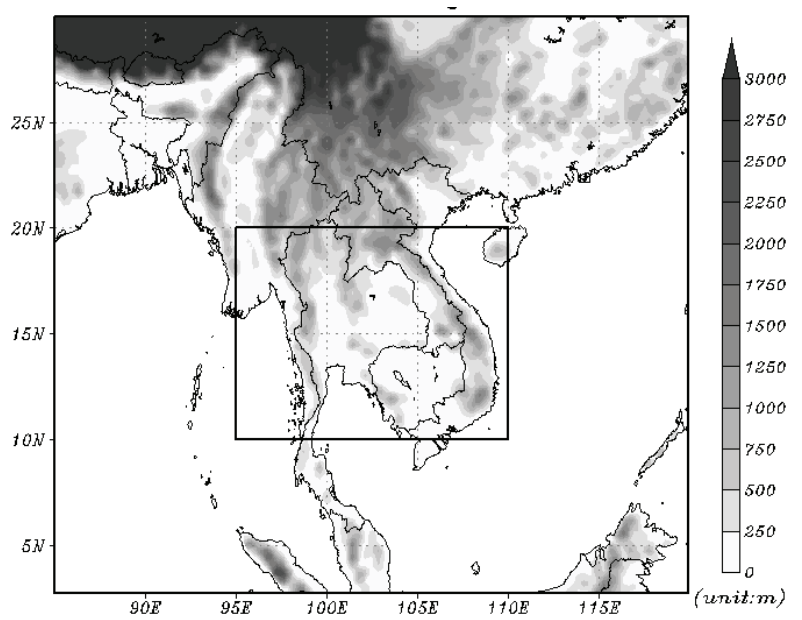

図-1 数値実験の計算領域. 図中の実線の四角で囲まれた範囲 は観測値、計算結果を空間平均した領域.

行った. 標準実験（CTL）では現実的な山岳と水平一様

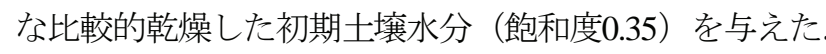
2つ目は山岳を取り除いた実験（NOMNT）で，他の条 件はCTLと同じである.3つ目は現実的な山岳を与えて, 非常に湿潤な初期土壤水分（飽和度1.0）に設定した実 験（WET）である.これらのアンサンブル数值実験か ら, 山岳と地表面の湿潤状態が夏季アジアモンスーンの オンセットに対してどのような役割を果たしているのか を検討する。

\section{3. 東南アジアモンスーンオンセットにおける山 岳と土壤水分の役割}

\section{（1）陸域水文過程の変化}

モデルの計算結果について，アンサンブル平均した降 水を日単位の全球降水データセットGlobal Precipitation Climatology Project (GPCP) ${ }^{23}$ と比較した（図-2）。観 測值と計算結果は図-1の実線で囲まれる領域（北緯10度 から20度，東経95度から110度）の陸上で空間平均した。 図-2に示される観測による降水は，4月中旬に比較的強 い降水イベント（7.5mm/day）を示し，また，5月上旬か ら中旬に急激な降水の増加が見られる.

CTL実験は観測に見られるモンスーンのオンセット前 後における降水の変化は概水良く再現できていた.

NOMNT実験では4月中旬の降水イベントは比較的再現 できていたが，5月の降水の急激な増加を全く再現でき ていなかった．WET実験では，4月のプレオンセット期 に過大な降水が生じている．しかしながら，5月中旬の 強い降水に関しては比較的よく再現できていた. CTL実 験と観測の相違は，モデルの物理過程によって生じた内 部循環による系統的誤差と，特に山岳地域で大きい観測 の不確実性 ${ }^{15,24}$ に起因すると考えられる.

図-3は各アンサンブル実験において北緯10度から20度, 東経95度から110度の陸上で領域平均した顕熱, 潜熱, 
表-1＼cjkstart東南アジアにおける水文過程の変化（北緯10度から20度, 東経95度から110度における陸上での平均）

\begin{tabular}{|c|c|c|c|c|c|c|c|c|c|}
\hline \multirow{2}{*}{$\begin{array}{c}\text { Elements of } \\
\text { hydrological cycle }\end{array}$} & \multicolumn{3}{|c|}{ CTL } & \multicolumn{3}{|c|}{ NOMNT } & \multicolumn{3}{|c|}{ WET } \\
\hline & $4 / 10-4 / 30$ & $5 / 1-5 / 20$ & Difference & $4 / 10-4 / 30$ & $5 / 1-5 / 20$ & Difference & $4 / 10-4 / 30$ & $5 / 1-5 / 20$ & Difference \\
\hline Precipitation ( $\mathrm{mm} /$ day) & 2.20 & 5.04 & $+2.84(+129 \%)$ & 1.92 & 2.05 & $+0.12(+6 \%)$ & 2.80 & 4.39 & $+1.59(+57 \%)$ \\
\hline Sensible Heat $\left(W / m^{\wedge} 2\right)$ & 62.12 & 31.69 & $-30.43(-49 \%)$ & 55.08 & 43.78 & $-11.3(-21 \%)$ & 18.70 & 19.65 & $+0.95(+5 \%)$ \\
\hline Latent Heat $\left(\mathrm{W} / \mathrm{m}^{\wedge} 2\right)$ & 73.26 & 76.35 & $+3.09(+4 \%)$ & 74.33 & 61.59 & $-12.74(-17 \%)$ & 121.70 & 93.78 & $-27.92(-23 \%)$ \\
\hline Soil Mixing Ratio $(\mathrm{g} / \mathrm{Kg})$ & 11.16 & 13.72 & $+2.56(+23 \%)$ & 12.49 & 13.57 & $+1.07(+9 \%)$ & 14.61 & 14.63 & $+0.01(*)$ \\
\hline $2 \mathrm{~m}$ Temparature $\left({ }^{\circ} \mathrm{C}\right)$ & 26.84 & 25.81 & $-1.03(-4 \%)$ & & & $-0.76(-3 \%)$ & 24.46 & 24.99 & $+0.53(+2 \%)$ \\
\hline
\end{tabular}

注 : 観測の降水 (GPCP) の変化は, $1.49 \mathrm{~mm} / \mathrm{day} （ 4 / 10-4 / 30 ）$ から5.16 mm/day (5/1-5/20)，その変化は+3.67 mm/day (+246\%) NOMNT実験の $2 \mathrm{~m}$ 気温に関しては, 他と比較するためには高度補正が必要となる。混乱を避けるため, 表には变化のみ記した

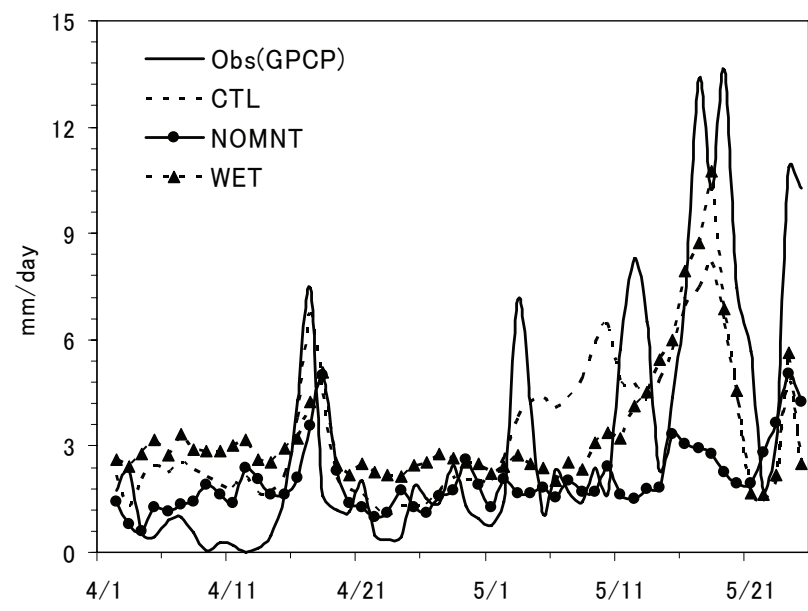

図-2＼cjkstart観測と数値モデルによって計算された降水量の1998年4 月2日から5月25日の期間の時間変化．降水量は，北緯10 度から20度, 東経95度から110度の領域の陸上で空間平 均を行った. 実線がGPCPによる降水. CTL, NOMNT, WET実験の降水は，それぞれ，点線，丸印付きの実線， 三角印付きの点線である.

土壌水分状態を反映し，地表面の蒸発の計算に直接反映 される変数である地表面の水蒸気混合比 ${ }^{25}$ （以後土壤 水分とする）の時間変化である，表-1は，プレオンセッ 卜の時期（4月10日から30日）とオンセットの時期（5月 1日から20日）の平均とその差を示したものである. 図一 3aと表-1に示されるように，CTL実験のアンサンブル平 均においては，急激な顕熱の減少 (-30.43 W/m², -49\%) と潜熱の若干の増加 $\left(+3.09 \mathrm{~W} / \mathrm{m}^{2},+4 \%\right) ，$ 土壌水分の 増加（+2.56 g/Kg, +23\%）がみられる。これらの変化は, 乾季から雨季に移り変わるこの時期における降水の増加

(+2.84 mm/day, +129\%) と地上気温の低下 $\left(-1.03{ }^{\circ} \mathrm{C}\right.$, 4\%）と一致している。このCTL実験における変化は, ある 1 地点における観測結果とその絶対值について直接 の比較はできないけれども，Todaら ${ }^{26)}$ に報告された観 測結果と整合的である。ただし，土地被覆の異なる別の 観測地点においては，降水，地表の土壤水分が少ない乾 季に，植生の蒸散によって潜熱が最大となることが報告 されており ${ }^{27)}$ ，更なる観測と議論が必要である. CTL実 験のプレオンセットの降水は，観測の降水（1.49 mm/day）よりもやや過大であるが，観測（+3.67mm/day， a)

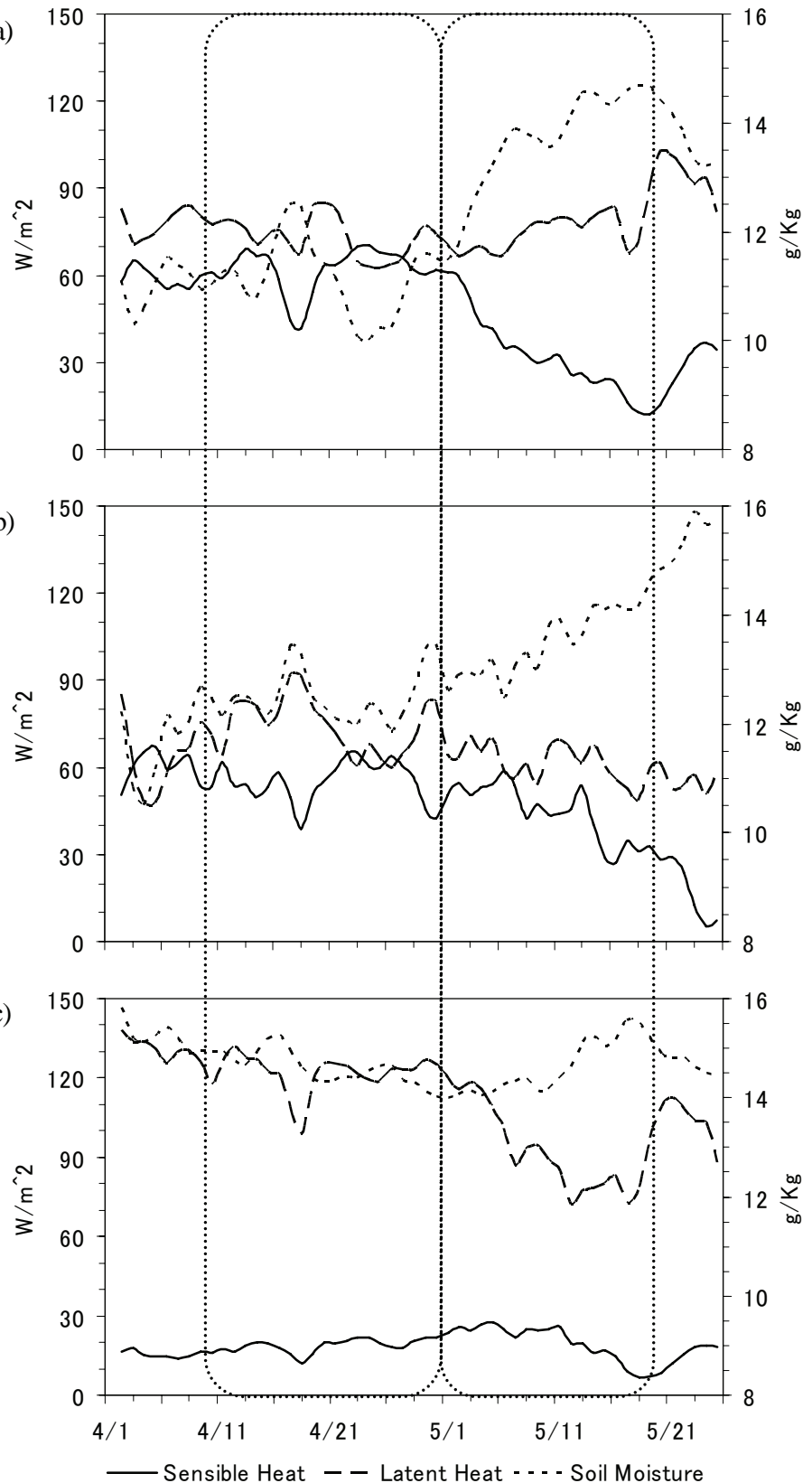

図-3 1998年4月2日から5月25日の期間における，北緯10度か ら20度，東経95度から110度の範囲の陸上で平均した顕 熱，潜熱，土袞水分の時間変化，a) CTL， b) NOMNT, c) WET実験．点線は表-1の2つの期間 

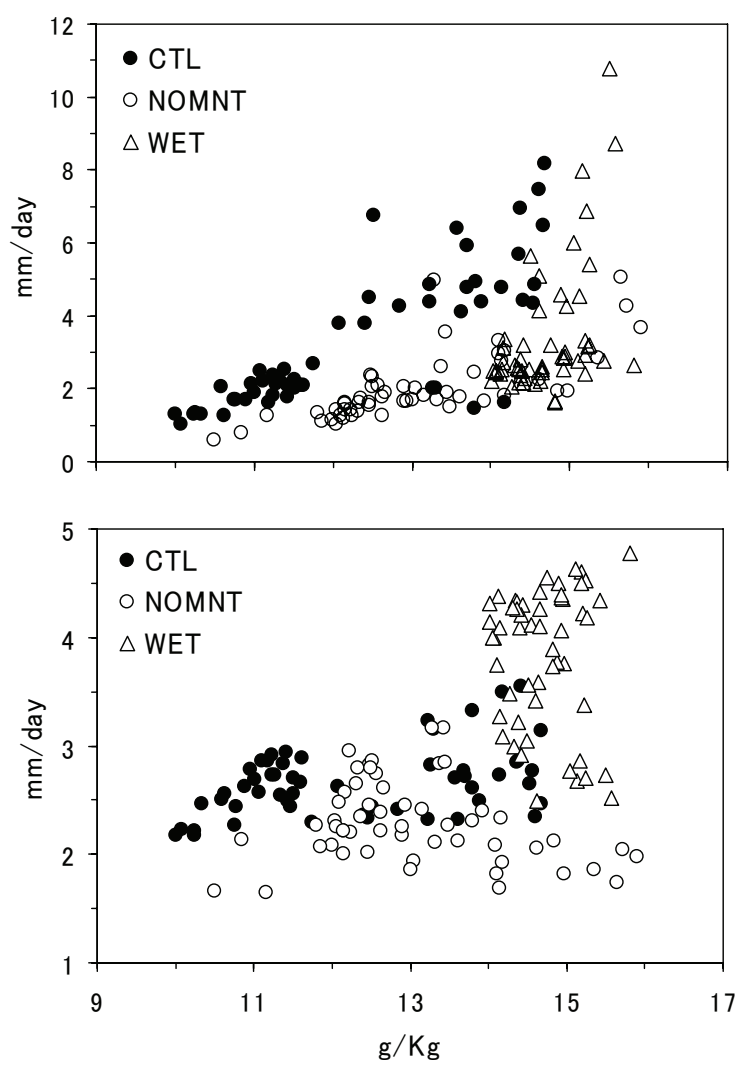

図-4 土袞水分と降水量の関係 (上図) と土壤水分と蒸発散量 の関係（下図）。CTL，NOMNT，WETはそれぞれ黒丸， 白丸，三角. 図中の各点は，4月2日から5月25日の期間 の日単位の計算結果を, 北緯10度から20度, 東経95度か ら110度の領域陸上で空間平均したもの.

表-2 4月2日から5月25日の期間における，それぞれの数値実 験における降水量と土壤水分, 蒸発散量と土壤水分の線 形回帰の傾きと決定係数.

\begin{tabular}{cllll}
\hline Experiment & & $\mathrm{CTL}$ & $\mathrm{NOMNT}$ & WET \\
\hline \multirow{2}{*}{ Increment of linear regression } & $\mathrm{P}$ & 1.00 & 0.57 & 1.97 \\
& $\mathrm{E}$ & 0.09 & -0.07 & -0.06 \\
\hline \multirow{2}{*}{ Coefficient of determination $\left(\mathrm{R}^{2}\right)$} & $\mathrm{P}$ & $0.62 *$ & $0.53 *$ & $0.25 *$ \\
& $\mathrm{E}$ & $0.18 *$ & 0.04 & 0.00 \\
\hline
\end{tabular}

* $1 \%$ significance level.

+246\%） と同様の大きな変化がみられる，オンセット期 における領域平均降水量はCTL実験の結果が最も観測に 近い.

図-3bと表-1では，顕熱 (-11.3 W/m², -21\%) と潜熱（$\left.12.74 \mathrm{~W} / \mathrm{m}^{2},-17 \%\right)$ がやや減少し，土壤水分が少し増加 している (+1.07 g/Kg, +9\%) 。これはNOMNT実験の才 ンセット時における弱い降水（+0.12 mm/day） と地上気 温の若干の低下 $\left(-0.76^{\circ} \mathrm{C}\right)$ と関係している.

図-3cは，ほとんど一定の小さな顕熱（4月10-30日は $18.70 \mathrm{~W} / \mathrm{m}^{2}$ ，5月1-20日は19.65 W/m²） と湿潤な土壤水分， 潜熱の若干の減少を示している (-27.92 W/m², -23\%). WET実験においては，プレオンセット期の降水が多い ため, CTL実験や，観測に比べて4月から5月の降水の相
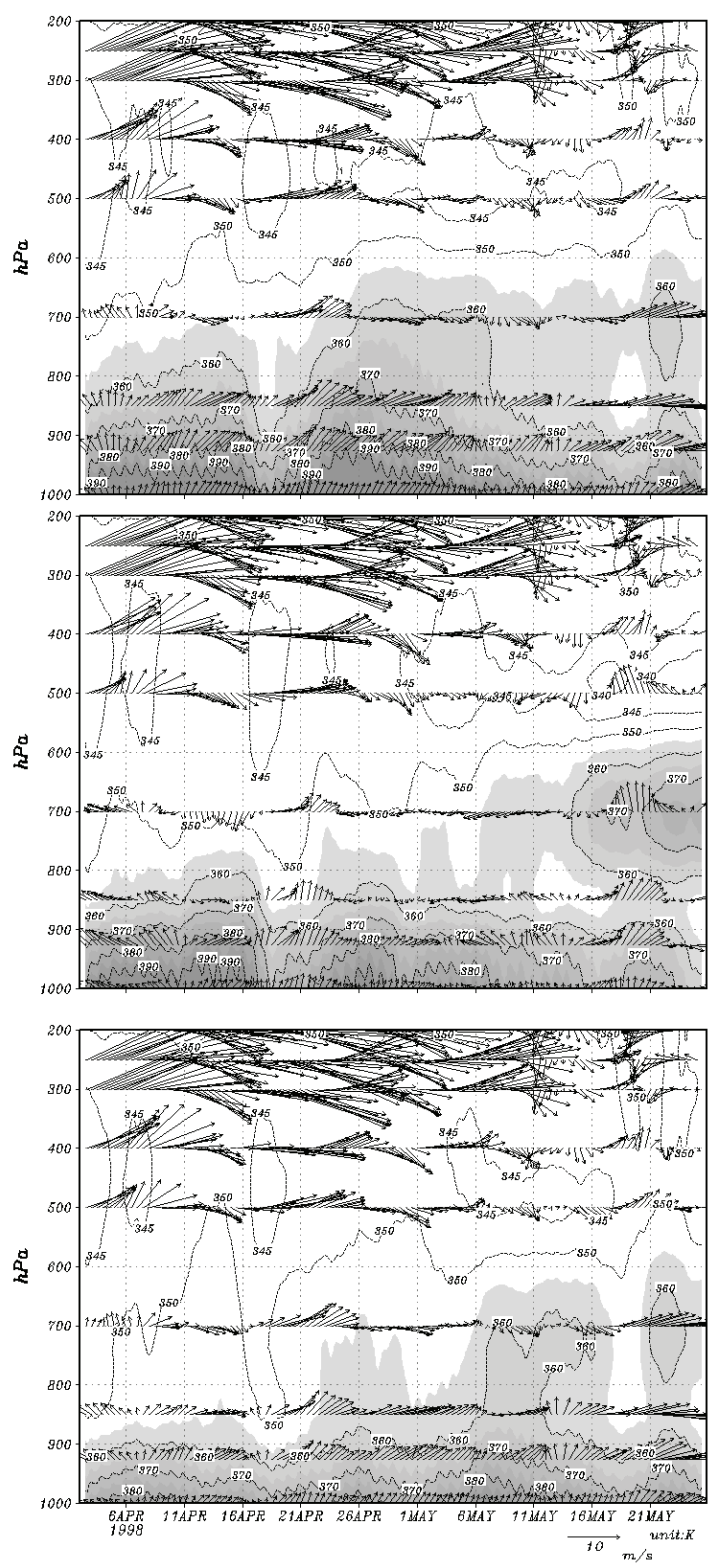

図-5 1998年4月2日から5月25日の期間について，北緯10度か ら20度, 東経95度から110度の陸上で領域平均した相当 温位 ·風ベクトルの高度一時間断面. 上図がCTL, 中の 図がNOMNT，下図がWETを示す。相当温位355K以上 は陰影を付けている.

対的な変化は小さい $(+1.59 \mathrm{~mm} / \mathrm{day},+57 \%)$. 地上気温 は，プレオンセット期にCTL実験よりもずっと低く（4

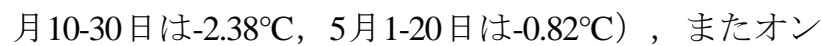
セット時に地上気温の低下が見られない $\left(+0.53^{\circ} \mathrm{C}\right.$, $+2 \%)$.

（2）降水一土壤水分関係

土畩水分はモンスーンオンセットの強さを大きく変化 させ，海陸の熱的コントラストに影響を及ぼす。図-4と 表-2は，それぞれの数值実験について，4月2日から5月 25日までの陸上における土壌水分と降水，蒸発散の関係 を示したものである. 図-4の上図と表-2に示されるよう に，CTL実験において，土壌水分と降水は統計的に有意 
な強い正の相関関係がある（傾き $1.00 \mathrm{~mm} / \mathrm{g} / \mathrm{Kg}$, 決定係 数0.62）. NOMNT実験とWET実験の場合も，統計的に は有意な正の相関関係がある（1\%有意水準）けれども， CTL実験と比べ，あまり明瞭でない相関関係を示してい る. また，CTL実験においては蒸発散と土壤水分は統計 的に有意な正の相関関係が見られるけれども（図-4の下 図，表-2），NOMNT，WET実験では有意な相関関係は みられない. オンセット期において, 山岳が降雨-土畩 水分関係の強さに大きな影響を及ぼしていることが示唆 され，現実的な山岳がある場合に，土壤水分の増加は蒸 発散を促進させる傾向が見られた。

図-5は，図-1の実線の四角で囲まれる領域平均の相当 温位と風の高度一時間断面を示したものである．CTL実 験では，プレオンセット期に対流圈下層において強い対 流不安定と南西風が生じている。 それは4月中旬の降水 や5月上旬の急激な降水の増加と一致している（図-2）。 NOMNT実験とWET実験では，特にプレオンセット期に 対流不安定と対流圈下層の風が弱い.

\section{4. 結論と考察}

数值実験結果は, 山岳と雨期開始前の地表面状態が東 南アジア夏季モンスーンの突然の始まりに強く影響する ことを示唆している.これまでの主に再解析データやG CMによる研究と今回の地域気候モデルによるアンサン ブル実験結果に基づき、インドシナ半島における夏季モ ンスーンのオンセット機構の仮説を示寸（図-6).

雨季開始前の乾燥した地表面と日射によって陸上にお ける強い顕熱加熱が生じ，地上気温を高め，海陸の熱的 コントラストを強め, 強い対流不安定が生じる ${ }^{10,28)}$ ，プ レオンセット期において地表面が湿潤な状態だった場合 には，プレオンセット期の降水を増やし，それが海陸の 熱的コントラストを弱め, モンスーン循環を弱める.さ らに蒸発冷却で地表面が冷やされ，対流不安定を弱める。

山岳は力学的・熱力学的に, 海陸の熱的コントラスト によって形成された熱的低気圧をある特定の地域に維持 し，強める働きをする ${ }^{13)}$. 山岳を取り除いた場合，対流 圈下層におけるモンスーン循環の強まりと関係する熱的 低気圧による上昇流が弱まる (not shown) 。地形によっ て励起された湿潤対流は大気を加熱し，モンスーン循環 を強め, 熱的低気圧によって引き起こされる収束を強化 寸る. また, 乾季功雨季の遷移期の降水は土㙵を湿ら せ，蒸発散を増やし，それがさらなる降水の供給源とな り，土壌水分一降水間に正のフィードバックが働く.

上部対流圈を東進するトラフや対流圈下層における水 蒸気流入はこの季節進行に重要な役割を持つと考えられ $る^{29}$. しかし，再解析デー夕を用いて現実的な側方・上 部境界条件を与えたにもかかわらず，数值モデルは地形 と比較的乾燥した陸面状態を与えた場合に東南アジアモ ンスーンオンセットによる水循環過程をよりよく再現で

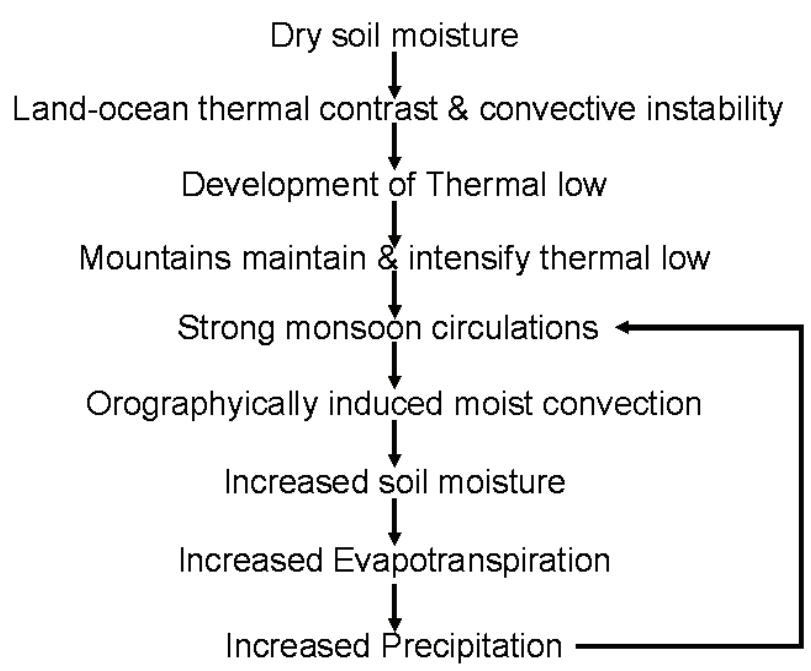

図-6 東南アジアにおける夏季モンスーンの急激なオンセット をもたらす力学, 熱力学過程, 水文過程の仮説.

きた.

対象としたGAME-IOPの1998年は, 全球規模の気候シ ステムが1997/1998年に東太平洋赤道付近に最も温かい 海面水温のアノマリがみられた状態から推移した. 寸な わち，全球規模の循環がENSOサイクルの温かいフェー ズ (El Niño) によって影響を受けた ${ }^{30)}$. 全球降水データ セット（GPCP）は，この1998年の東南アジア地域では 比較的降水が少なかったということを示している. ENSOに関係した全球規模の循環が東南アジア夏季モン スーンの始まりにどのような影響を及ぼしたのかについ てはよくわかっておらず，検討の余地がある。また， 1998年夏季アジアモンスーンの始まりの時期において, 山岳と内的フィードバックの重要性を示唆する本研究の 結果の一般性については, 今後さらに研究を進める必要 がある.

本研究は, GAME再解析データと高解像度地域気候モ デルを用いたアンサンブル数值実験によって, 東南アジ ア地域のモンスーンオンセットにおいて, 山岳と地表面 の湿潤度を含む非線形の効果によって, 現実的な降水の 急激な増加がもたらされ，地表面における熱収支の変化 を通して, 乾季から雨季にかけての遷移期における水循 環の変化を生じさせていることを示した. オンセット期 の降水は, さらなる降水の供給源として土壤からの蒸発 散を増加させることによって，土壤水分と降水間に正の フィードバックを生じさせていると考えられる.

謝辞 : 研究を進めるにあたり, 首都大学東京大学院都市 環境科学研究科の松本淳教授, 国立環境研究所の江守正 多室長，コロラド大学のRoger A. Pielke, Sr.教授には有益 な議論をして頂きました。 ここに記して感謝の意を表し ます。 


\section{参考文献}

1) Charney, J. G. and Shukla, J.: Predictability of monsoons, Monsoon Dynamics, Lighthill, J. and Pearce, R. P. eds., Cambridge University Press, Cambridge, UK., pp.99-109, 1981.

2) Fasullo, J. and Webster, P. J.: A Hydrological Definition of Indian Monsoon Onset and Withdrawal, J. Climate, Vol.16, pp.3200-3211, 2003.

3) Lau, K. -M. and Yang, S.: Climatology and Interannual Variability of the Southeast Asian Summer Monsoon, Advances in Atmospheric Sciences, Vol.14, pp.141-162, 1997.

4) Matsumoto, J.: Seasonal Transition of Summer Rainy Season over Indochina and Adjacent Monsoon Region, Adv. Atmos. Sci., Vol.14, pp.231-245, 1997.

5) Zhang, Y., Li, T., Wang, B. and Wu, G.: Onset of the Summer Monsoon over the Indochina Peninsula: Climatology and Interannual Variations, J. Climate, Vol.15, pp.3206-3221, 2002.

6) Webster, P. J.: Mechanisms of Monsoon Low-Frequency Variability: Surface Hydrological Effects, J. Atmos. Sci., Vol.40, pp.2110-2124, 1983.

7) Emori, S.: The interaction of cumulus convection with soil moisture distribution: An idealized simulation, J. Geophys. Res., Vol.103, pp.8873-8884, 1998.

8) Meehl, G. A. and Washington, W. M.: South Asian Summer Monsoon Variability in a Model with Doubled Atmospheric Carbon Dioxide Concentration, Science, Vol.260, pp.1101-1104, 1993.

9) Minoura, D., Kawamura, R. and Matsuura, T.: A Mechanism of the Onset of the South Asian Summer Monsoon, J. Met. Soc. Japan, Vol.81, pp.563-580, 2003.

10) Meehl, G. A.: Influence of the Land Surface in the Asian Summer Monsoon: External Conditions versus Internal Feedbacks, J. Climate, Vol.7, pp.1033-1049, 1994.

11) Goswami, B. N.: Interannual Variations of Indian Summer Monsoon in a GCM: External Conditions versus Internal Feedbacks, J. Climate, Vol.11, pp.501-522, 1998.

12) Yang, S. and Lau, K. -M.: Influences of Sea Surface Temperature and Ground Wetness onAsian Summer Monsoon, J. Climate, Vol.11, pp.3230-3246, 1998.

13) Hahn, D. G. and Manabe, S.: The Role of Mountains in the South Asian Monsoon Circulation. Journal of the Atmospheric Sciences, $J$. Atmos. Sci., Vol.32, pp.1515-1541, 1975.

14) Kitoh, A.: Effects of Mountain Uplift on East Asian Summer Climate Investigated by a Coupled Atmosphere-Ocean GCM, $J$. Climate, Vol.17, pp.783-802, 2004.

15) Dairaku, K., Emori, S. and Oki, T.: Rainfall Amount, Intensity, Duration, and Frequency Relationships in the Mae Chaem Watershed in Southeast Asia, J. Hydrometeor., Vol.5, pp.458-470, 2004.

16) 大楽浩司, 江守正多, 沖大幹, 虫明功臣 : 領域気候モデル を用いた東南アジア熱帯山岳地域における降水特性の解析, 水工学論文集, Vol. 47, pp.79-84, 2003.
17) Pielke, R. A., Cotton, W. R., Walko, R. L., Tremback, C. J., Lyons, W. A., Grasso, L. D., Nicholls, M. E., Moran, M. D., Wesley, D. A., Lee, T. J. and Copeland, J. H.: A comprehensive meteorological modeling - RAMS, Meteorol. Atmos. Phys., Vol.49, pp.69-91, 1992.

18) Molinari, J.: A General Form of Kuo's Cumulus Parameterization, Mon. Weath. Rev., Vol.113, pp.1411-1416, 1985.

19) Harrington, J. Y., Reisin, T., Cotton, W. R. and Kreidenweis, S. M.: Cloud resolving simulations of Arctic stratus. Part II: Transitionseason clouds, Atmos. Res., Vol.51, pp.45-75, 1999.

20) Walko, R. L., Band, L. E., Baron, J., Kittel, T. G. F., Lammers, R., Lee, T. J., Ojima, D., Pielke, R. A., Taylor, C., Tague, C., Tremback, C. J. and Vidale, P. L.: Coupled Atmosphere-Biophysics-Hydrology Models for Environmental Modeling, J. Appl. Meteorol., Vol.39, pp.931-944, 2000.

21) Reynolds, R. W., Rayner, N. A., Smith, T. M., Stokes, D. C. and Wang, W.: An Improved In Situ and Satellite SST Analysis for Climate, J. Climate, Vol.15, pp.1609-1625, 2002.

22) Yamazaki, N., Kamahori, H., Takahashi, K. and Yatagai, A.: On the GAME reanalysis, UCLA Trop. Meteorol. Newsl., Vol.44, 2001.

23) Huffman, G. J., Adler, R. F., Morrissey, M. M., Bolvin, D. T., Curtis, S., Joyce, R., McGavock, B. and Susskind, J.: Global Precipitation at One-Degree Daily Resolution from Multisatellite Observations, J. Hydrometeor., Vol.2, pp.36-50, 2001.

24) Xie, P. and Arkin, P. A.: Global Precipitation: A 17-Year Monthly Analysis Based on Gauge Observations, Satellite Estimates, and Numerical Model Outputs, Bull. Amer. Meteor. Soc., Vol.78, pp.2539-2558, 1997.

25) Lee, T. J. and Pielke, R. A.: Estimating the Soil Surface Specific Humidity. J. Appl. Meteor., Vol.31, pp.480-484, 1992.

26) Toda, M., Nishida, K., Ohte, N., Tani, M. and Musiake, K.: Observations of Energy Fluxes and Evapotranspiration over Terrestrial Complex Land Covers in the Tropical Monsoon Environment, J. Met. Soc. Japan, Vol.80, pp.465-484, 2002.

27) Tanaka, K., Takizawa, H., Tanaka, N., Kosaka, I., Yoshifuji, N., Tantasirin, C., Piman, S., Suzuki, M. and Tangtham, N.: Transpiration peak over a hill evergreen forest in northern Thailand in the late dry season: Assessing the seasonal changes in evapotranspiration using a multilayer model, J. Geophys. Res., Vol.108, doi: 10.1029/2002JD003028, 2003.

28) Kawamura, R., Fukuta, Y., Ueda, H., Matsuura, T. and lizuka, S.: A mechanism of the onset of the Australian summer monsoon, $J$. Geophys. Res., Vol.107, doi:10.1029/2001JD001070, 2002.

29) Kiguchi, M, and J. Matsumoto, The rainfall phenomena during the pre-monsoon period over the Indochina peninsula in the GAME-IOP year,1998, J. Met. Soc. Japan, 83, 89-106, 2005.

30) Anyamba, A., Tucker, C. J. and Mahoney, R.: From El Nino to La Nina: Vegetation Response Patterns over East and Southern Africa during the 1997-2000 Period, J. Climate, Vol.15, pp.30963103, 2002.

(2006. 9. 30受付) 